International Journal of Engineering \& Technology, $7(3.21)(2018) 547-551$
International Journal of Engineering \& Technology
SPC
Website: $\frac{\text { www.sciencepubco.com/index.php/IJET }}{\text { Research paper }}$

\title{
Nurturing Moral Values Among the Children: Insights from Dance and Drama-Based Learning
}

\author{
Ramlan $^{1 *}$, Abdul Rozak ${ }^{2}$, Fikriyah $^{3}$, Nurkholis $^{4}$, Yusuf Ibrahim ${ }^{5}$ \\ ${ }^{1,5}$ Universitas Pasundan, Jl. Setiabudhi 193 Bandung 40154, Indonesia \\ ${ }^{2}$ Universitas Swadaya Gunung Jati, Jl. Perjuangan 32 Cirebon 45135, Indonesia \\ ${ }^{3,4}$ Universitas Muhammadiyah, Jl. Tuparev 70 Cirebon 45153, Indonesia \\ *Corresponding author E-mail: ramlanmsn@unpas.ac.id
}

\begin{abstract}
Emerging the immoral behavior being the challenges in Indonesia during the last few decades needs to have alternative approach implemented in the learning process. The serious reconstruction of the national education curriculum has to be conducted into designing the alternative concept, especially inculcating the moral personality within the exciting programs. Among those programs with offering exciting programs, one of them is dance and drama basis. This paper aims to explore the way to inculcate moral values among the children through dance and drama based learning. Literature analysis was conducted from peer reviewed books and journals using the theme of dance and drama based learning. The results indicate that there are three core basis of delivering learning basis of arts where both refer to sharing the art with a significant professional experience to connect with each other in realizing to feel emotional similarities, potential in shaping moral values. Those are the process of receiving knowledge in the sense of sharpening performance with managing the learning habit. This study is expected to contribute to the conceptual basis on how to inculcate the moral values among the children. Thus, moral education should be optimized within this co-curricular program.
\end{abstract}

Keywords: character education; learning model; dance and drama

\section{Introduction}

Emerging the moral challenges like violence, cheating, mischievous acts, and vandalism traits among many adolescents in some part of Indonesia makes a worry about the educational system implementation. Although the current educational program set out in the national curriculum design $(1,2)$, the gap on the stage of implementation in the co-curricular program is still needed to explore in the particular approach. The ethical engagement is needed in order to when viewing these days are so worrying, many incidents about the violation of law, and the violation of ethics, from the people in the society, to the government officials. The incidents that are happening these days are corruption; the misuse of drugs; abuse; war between ethnic group; place of worship's destructions; slander; and murder (3). It might be not exaggerate if the social observer opined that the phenomena in Indonesia these days is in the 'moral crisis' condition.

Especially the things that involving students and college students, the phenomena that are happening these days are : (1) the habit of 'cheating' during test that are still done; (2) the desire to pass with shortcut without any hard work on national exam cause them to find the answers with unethical ways; (3) plagiarism of scientific work around college students that are massive; (4) brawls between students and college students; (5) liquor drinking, promiscuity, and drugs; and (6) 'students gang' and 'motorcycle gang' which often lead to criminal actions like abuse, even murder (4).

The observers from various disciplines, have a certain views that the phenomena in Indonesia like what explained above, are closely related to human's character. Humans, since born, already have the characters that were shaped through heredity factor. Potential which is innate from birth is not going to develop just like what expected if there is no development process through education. Facing the nation's problem that are viewed to be related to the failure of Indonesia's government in education's sector, on Republic Indonesia's newest national curriculum concept named 'Kurikulum 2013', it is very clear contains character education concept. This becomes a new challenge for teachers, to immediately taught only to give birth to intelligent people, to be prioritized to shape the character of leaners, so that in the future will give birth to a nation of character.

Facts in field, to change the teaching mindset are not easy, the teachers are still teaching with old habit or in conventional ways. According to the teachers, to do the learning method as required by guided to the new curriculum policy is not easy, so many obstacles ahead of them, such as in general linked with the limitations of the education of 'Learning Model' utilization which relevant with the education's purpose. Dance and drama lesson are very potential in shaping the student's character. Through the learning process, the students are not only receiving educations, but will also do sense shaping practices repeatedly through art practices. In the end, will have the 'permanent' habit, which is the accumulation of values in character education.

\section{Literature Review}

\subsection{Moral Values in Character Education}

Moral values are considered as the principles with behaving the sense to do the good thing (5), where the personality standard is 
the main goal (6). It refers to the way on how to interact with others in a particular way within the curriculum design (7). As the ideals and principles which can be used for nurturing the individual personality with moral enhancement, the orientation in making the personal habit refers an attempt to shape the students' character facilitated by the instructoror teacher in the learning class (8).There are many types of initiative to deliver the moral enhancement that guide how the individual personality should act, which consists of attitude generally referring to the orientation of the raise into others in the way which configures the standards to act (1).It remains the process of character education to involve three components namely moral knowing; moral feeling; and moral action (9).It refers to the entire effort to inculcate the moral values both religious foundation and ethical engagement (10).

Moreover, moral action which is entirely connected to the character is closely related to the question of value. Converged into seeing someone's action, whether good or bad value, some values in human's life surrounding in underlying their thought, speech, and action (11) can be initiated through teaching by giving information to the students about which one is right and which one is wrong (12). As a result, character education points out the process of character building through learning on every lesson at class. In terms of planning configured into the character education, habitual approach should be engaged into the classroom basis and societal concern(13). Through conducting the good things initiated by the students, continuous effort needs to construct especially in the way of giving the habit training. Since the personal habituation has a significant role to nurture the morality, the consistency to inculcate the moral values is the core point as an entire attempt to do the good things by knowing the good things and get used to do it. With this regard, the more the students will consistently conduct such acts, the more they become more influenced to always do the good things.

\subsection{Significance of Drama and Dance in Character Ed- ucation}

The drama is the most stimulating form of literature because attempts to learn by doing with addressing one lives by being-acting are exhilarated living (14). Interpreting a part or reading will play with imagination demands into careful character analysis from work with the drama. Moreover it needs to enhance the initiative to learn by observing the people you meet in life and literature more closely and to develop sympathy for human being because you understand better their motives and problems.

In dance and drama, there are values which are aesthetic, ethics, religious, and social (15). The values are carried and present in the shape of intellectual, emotional, visual, and verbal. Education through dance and drama medium, stimulate the student's interest, to achieve educations as much as possible, also to manifest chained effect. Learning dance and drama, also learning language, literature, talking in rhythm, memorize technic, thinking, and various life educations (16). These six fundamental patters have a pivotal meaning from the analysis of the possible distinctive modes of human understanding. These six patterns may be designed respectively as symbolic, empirics, esthetics, ethics, and synoptic (17). If six patterns of human life meaning need the requirement to be owned by human ideally, it should be addressed in the way on integrating the internalization patterns in the shape of activities since elementary school especially on lower grades. The elementary school student's activities with addressing psychological approach needs to play through applying dance and drama games (18). Because this actof dance and drama appreciation points out the learning activity about life through language symbols (19), the activity of dance and drama presentation is the transformation of empiric life values into symbolic life values on the stage. The dance and drama activity as audience as well as the performance is the process of learning about human life values through symbolization $(20,21)$. The activity of interpretation and dance and drama presentation is the exploitation awareness activity about meaning of life experiences and human life.

\subsection{Towards Learning Enhancement}

According to (22), project based learning is a learning model that is innovative which in the process is pushing on the contextual learning through complex activity. Other than that, the learning model gives strong emphasis on problem solving. Next, according to Thomas (23), the learning focus on project based learning model is placed on concepts and main principles from a study discipline, involving students on problem solving investigation and any meaning tasks, to give students to work in autonomous to construct themselves, and to reach the peak, to create real product. Model problem based learning is a learning approach by making confrontation to students by simple problems or the learning that is started by giving problems and have real life context (24). This model will train students to use themselves to pay attention about their community environment. On Inquiry Based Learning model, students will get researching practice experiences to develop their ability to think and be scientific including on asking questions, planning, and using tools and data collection technique also communicating the arguments scientifically.

In terms of the purpose of inquiry learning, there are some which can manage the students to learn scientific method and able to apply it on another situation $(25,26)$. There are also stages on inquiry learning that are : (1) the students are stimulated by the teacher with some problems, statements, questions, games; (2) by the stimulate, the students decide the procedure to find and collect the information to solve the problem; (3) students appreciate the knowledge gained by inquiry that has just been done; and (4) the student conducts an analysis of the method of inquiry and the procedure specified to be a method which can be applied to a new atmosphere.According beside related with research learning, discovery based learning model is the learning process that involving maximally the student's ability to search and find something (things, human, or incidents) systematically, critically, logically, analytically, so the students can formulate their research themselves with full of pride (27).By using a discovery based learning model used by teachers repeatedly, will be able to improve the ability of students to find something. The use of discovery based learning model wants to change the condition of passive learning process become active and creative.

\section{Methodology}

This paper aims to explore the way to inculcate moral values among the children through dance and drama approach within the learning. Literature analysis was conducted from peer reviewed books and journals using the theme of dance and drama based learning. Attempt to using research \&development approach is usually adopted to examine the basis of object with approach of the step to develop method product that is still hypothetic, using experiment with action research. Special purpose of this research is to have new knowledge about learning model that should be used by the elementary school teachers on teaching dance and drama. As for learning model that is intended on this Research and Development is a learning model.This research object is elementary school teachers who teach dance and drama, and the focus of this research is what related with shaping the student's character, then, the most appropriate research object is the first, second, and third grade elementary teachers. As for the location of this study are the schools in Karawang city, Indonesia. 


\section{Analysis and Discussion}

\subsection{Results and Finding}

From the survey results that was done at schools, found that mostly teachers who are currently teaching dance and drama, is not relevant to the purpose of learning. For examples, the teacher teaches to the students to memorize one traditional dance, they just show the picture, and not teaching the student on how to learn the art practice. On picture below, we are looking at how dance and drama teachers teach their students on the learning process at class.

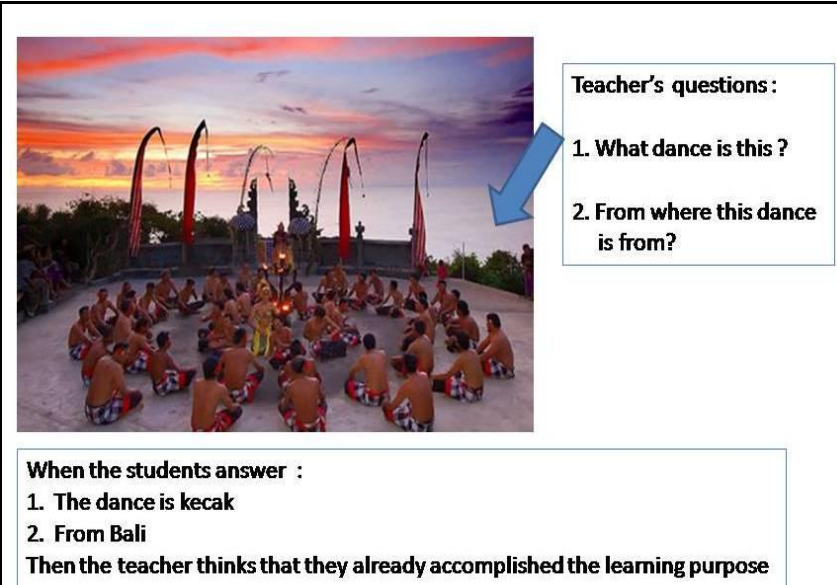

Fig. 1: Facts about dance $\&$ drama teacher teaching at class

Art and culture learning at school like what already explained on picture above is 'misguided', because not relevant with art education concept. Art education concept is 'sense education', and the purpose of art and culture education at school is to develop 'sense of art' potential on children's individual. Therefore, if the students is just given rote learning and not doing practical learning, then it's not 'meaningful' in the end will not be relevant with educational purpose, which is to produce the clever and characterized nation.

Describes how teachers do not have the readiness to implement the learning process to form the character of students. The table 1 is the results of the interview.

Table 1: Interview of elementary school teachers in implementing character education

\begin{tabular}{|c|l|l|}
\hline NO & \multicolumn{1}{|c|}{ QUESTION } & \multicolumn{1}{c|}{ ANSWER } \\
\hline 1 & $\begin{array}{l}\text { How do you teach to shape } \\
\text { the character of the stu- } \\
\text { dents? }\end{array}$ & $\begin{array}{l}\text { By giving example and role models } \\
\text { to the students }\end{array}$ \\
\cline { 3 - 3 } & $\begin{array}{l}\text { Explain to the students that honest } \\
\text { and tolerance are good }\end{array}$ \\
\hline 2 & $\begin{array}{l}\text { How do you teach dance \& } \\
\text { drama to shape the charac- } \\
\text { ter of the students? }\end{array}$ & $\begin{array}{l}\text { Many teachers cannot answer the } \\
\text { questions }\end{array}$ \\
\hline 3 & $\begin{array}{l}\text { What is your goal on teach- } \\
\text { ing dance and drama in } \\
\text { elementary school? }\end{array}$ & $\begin{array}{l}\text { So that students will have skills in } \\
\text { playing dance \& drama }\end{array}$ \\
\hline & $\begin{array}{l}\text { Why do not you implement } \\
\text { teaching to shape the stu- } \\
\text { dent's character? }\end{array}$ & $\begin{array}{l}\text { Have no knowledge to implement } \\
\text { character education -based learning }\end{array}$ \\
\cline { 3 - 3 } & & $\begin{array}{l}\text { Already accustomed to teach con- } \\
\text { ventionally }\end{array}$ \\
\hline
\end{tabular}

In reality, currently the art and culture learning at schools mostly they are referring to the particular approach to develop their character (6). Attempts to acquire the heading from the theory into the practical level have a pivotal role to make the learning more accurate to the main goal. Learning process here refers to the impact from the unpreparedness teachers based on the learning purpose and rote which is inappropriate to the relevance of the art education concept (28). In terms of the teacher's competence on teach- ing to shape student's character, actually Republic Indonesia government since 2010 through National Educational Ministry had already done the coaching to educational units such as : (1) training system for the stakeholders. Such as training main level, training national level, training province level, training district/city level, training school stub level; (2) using trainer resource : already trained school principal, supervisor as a part of competence enhancement on managing, leading, and supervising teachers on developing the character education learning based; and (3) including character education values into socialization activity of curriculum preparation.

Even though already given various training by the government, but actually, the teachers are still doing the learning process at class with the conventional ways. The problem especially is really related with the lack of learning model education which could shape student's character. Learning model is management concept to organize a learning process, which is functioned as the guide for teachers to do their teaching activity, so the learning process will be actually leading to the actual purpose with pointing out determinants of quality student outcomes (29). The researcher's survey result can be analyzed so it got the findings, that the elementary teachers on teaching dance and drama does not have the knowledge of learning model as appropriate as it should be used especially the learning model that can shape the character of the student.

The table below is the results of research observation, describes how teachers in elementary school in using learning models that have an impact on the student's character shaping.

Table 2: Instruction for nurturing moral values among the students by

\begin{tabular}{|c|c|c|}
\hline NO & ACTIVIES & NOTE \\
\hline \multicolumn{3}{|c|}{ A. $\quad$ APPLICATION OF LEARNING MODELS } \\
\hline 1 & $\begin{array}{l}\text { Implementing learning in } \\
\text { accordance with competence } \\
\text { to be achieved }\end{array}$ & $\begin{array}{l}\text { Not clear }- \text { teachers teach } \\
\text { more by improvise }\end{array}$ \\
\hline 2 & $\begin{array}{l}\text { Implement learning system- } \\
\text { atically }\end{array}$ & $\begin{array}{l}\text { Not really mastering the class } \\
\text { many students who do not } \\
\text { concentrate on learning }\end{array}$ \\
\hline 3 & Mastering the class & $\begin{array}{l}\text { Not really mastering the class } \\
\text { - there are still many students } \\
\text { concentrate on learning }\end{array}$ \\
\hline 4 & $\begin{array}{l}\text { Implementing contextual } \\
\text { learning }\end{array}$ & Invisible \\
\hline 5 & $\begin{array}{l}\text { Implementing learning that } \\
\text { will enables the growth of } \\
\text { positive activities }\end{array}$ & Mostly possible \\
\hline 6 & $\begin{array}{l}\text { Implementing learning in } \\
\text { accordance with the planned } \\
\text { time allocation }\end{array}$ & Not clear \\
\hline 7 & $\begin{array}{l}\text { Grow the active participation } \\
\text { of students, through the } \\
\text { interaction of teachers, stu- } \\
\text { dents and the learning } \\
\text { sources }\end{array}$ & A small portion is visible \\
\hline 8 & $\begin{array}{l}\text { Respond positively to the } \\
\text { student's participate }\end{array}$ & Mostly visible \\
\hline 9 & $\begin{array}{l}\text { Shows an open attitude to- } \\
\text { ward the response of the } \\
\text { students }\end{array}$ & Partly visible \\
\hline 10 & $\begin{array}{l}\text { Shows a conducive interper- } \\
\text { sonal relationship }\end{array}$ & $\begin{array}{l}\text { Mostly visible, but there are } \\
\text { still many passive students }\end{array}$ \\
\hline \multicolumn{3}{|c|}{ B. CHARACTER SHAPING ACTIVITIES } \\
\hline 1 & $\begin{array}{l}\text { Involving students in charac- } \\
\text { ter for shaping : Religious }\end{array}$ & Not clear \\
\hline 2 & $\begin{array}{l}\text { Involving students in charac- } \\
\text { ter shaping : Honesty }\end{array}$ & Not clear \\
\hline 3 & $\begin{array}{l}\text { Involving students in charac- } \\
\text { ter shaping : Tolerance }\end{array}$ & $\begin{array}{l}\text { There are some - when chil- } \\
\text { dren start learning dance tech- } \\
\text { niques - in turns }\end{array}$ \\
\hline 4 & $\begin{array}{l}\text { Involving students in charac- } \\
\text { ter shaping : Discipline }\end{array}$ & $\begin{array}{l}\text { There are some - Mostly learn } \\
\text { by chatting with friends }\end{array}$ \\
\hline 5 & $\begin{array}{l}\text { Involving students in charac- } \\
\text { ter shaping : Hard work }\end{array}$ & invisible \\
\hline
\end{tabular}




\begin{tabular}{|c|l|l|}
\hline NO & \multicolumn{1}{|c|}{ ACTIVIES } & \multicolumn{1}{|c|}{ NOTE } \\
\hline 6 & $\begin{array}{l}\text { Involving students in charac- } \\
\text { ter shaping : creative }\end{array}$ & invisible \\
\hline 7 & $\begin{array}{l}\text { Involving students in charac- } \\
\text { ter shaping : independent }\end{array}$ & invisible \\
\hline 8 & $\begin{array}{l}\text { Involving students in charac- } \\
\text { ter shaping : democratic }\end{array}$ & There are - a small part \\
\hline 9 & $\begin{array}{l}\text { Involving leaners in character } \\
\text { formation : curiosity }\end{array}$ & invisible \\
\hline 10 & $\begin{array}{l}\text { Involving students in charac- } \\
\text { ter shaping : the spirit of } \\
\text { nationalism }\end{array}$ & invisible \\
\hline 11 & $\begin{array}{l}\text { Involving students in charac- } \\
\text { ter shaping : to love their } \\
\text { homeland }\end{array}$ & invisible \\
\hline 12 & $\begin{array}{l}\text { Involving students in charac- } \\
\text { ter shaping : Appreciate } \\
\text { achievement }\end{array}$ & invisible \\
\hline
\end{tabular}

From table 2 above can be taken some findings, elementary school teachers: (1) in carrying out the learning process is still using conventional ways; (2) has not been able to change the mindset of the purpose of teaching for intelligent humans only, be teaching to give birth to intelligent and characterized human being; and (3) to carry out the character-taught learning process, especially for teachers who teach dance $\&$ drama, requires an effective learning model and towards the goal. In order to drive the process itself into the enhancement to the target in terms of caring with others, nurturing compassionate based empathy could be one of the sources supposed in the way as an effort to contribute to such learning models where the potential enhancement with dance \& drama should be inculcated in a particular way $(21,30)$. Attempts to inquire the use of teaching style here point out the use of the learning model only $(19,20)$. As a result, it is necessary to strengthen the style itself through modification, collaboration, and adaption to all four learning models to fit the character in the fields of art, especially the art of dance \& drama that become the subject matter in elementary school.

The four learning models have similarities that can be used to teach dance \& drama art in elementary school, such as : (1) use project/activity as the media; (2) students do the exploration, assessment, interpretation, synthesis, and information to produce various forms of learning outcomes; (3) a learning approach that present a contextual problem thus stimulating leaners to learn; (4) students work in teams to solve real-life problem; (5) the subject matter is not presented as a final form, but the students organize themselves, and (6) the teachers act as mentors by giving opportunities for the students to learn actively.

Referring to the national curriculum policy of the Indonesian republic, the learning models which need to be prioritized for teaching in schools are inquiry based learning, problem based learning, discovery based learning, and project based learning (10). It points out the necessary learning models with the significant insights in building civic engagement to get involved in social events awareness and goodwill from the community (31). Towards different aspects of group or organization engaged into the scholarship and civic responsibility, attempts to put responsible citizens and active participants in the community has to be inculcated with the mindful feeling of self and social empathy (32). The initiative to enhance learning basis should refer to the dynamics of learning with ethical consideration (33). In terms of mechanical aids and rules to strengthen ethical engagement in addressing the moral purpose to promote sustainable learning, effort should be developed to enhance the awareness with the ability to interact and care among the students (25). With providing the framework to incorporate technology for example smartphone use in teaching and learning to create attractive teaching and optimum interaction with students in classes $(34,35)$, adaptive technology skills are needed in providing a considerable guidance for child protection and careful engagement towards digital information (36).

In terms of the current issue, advancement and the perfection of the individual and the society through the methodology for dis- pensing and acquiring knowledge (37), attempts to assist the knowledge configured into the instructional design with ethical engagement to strengthening the process of learning and teaching are central in the process of transfer both knowledge and value (38). The result reveals that there are some processes of modification, collaboration, and adaption of the learning models as should be prioritized in teaching according to the nation curriculum of the Indonesian republic government. To get the discovery of learning model of dance and drama that has been done and study on the concept of art education and character education. The study process explained is described as shown below.

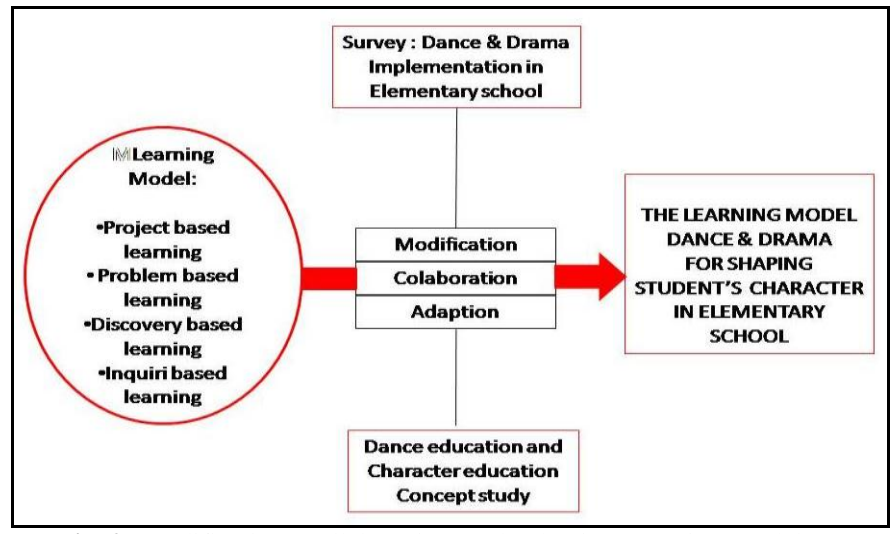

Fig. 2: Modification, Collaboration, and Adaption Learning Model

The research result is found that the learning model to teach dance and drama in elementary school which is character shaping based effectively and on the target, is through this learning process:

a. Preliminary stage : (1) Teacher tells true story about themselves or other people, the true story that was told by the teacher is the meaningful story to be understood by the students which is ended by the good things, on the story should be daily life problems that needs to be solved; (2) students are given the chance to give comments or to ask to the teacher, which is related to the real life story; (3) students are given the chance to tell their experience; and (4) the teachers divide the class into small groups.

b. Preparation of performance practice stage :(1) a set of students' stories on their groups, choose one story to be the title of the dance and drama artwork; (2) the chosen story, then they write to be a script or scenario of dance and drama performance; (3) students choose the casts who are needed on the performance script; and (4) students discussing to prepare the practices.

c. Performance and discussion stage : (1) the work of students from the performance practice on stage (permanent stage or simple) ; (2) the order is made by the students groups, in order according to the students' deal; (3) the groups who have not been able to perform on stage, become not only audience or supporter, but also given task by the teacher to write down the important parts to be the discussion material (for higher grades), and given task to remember the story of the dance and drama (for lower grades); and (4) discussion leaded by the teachers. And the teacher concludes the result from the learning process.

d. Closing stage: The teachers and students conclude the entire learning activity process. Students should get the information - that the learning activity process is already hit the purpose. The findings of dance \& drama learning models have previously been through the design validation phases, design trials, product trials and end with trial usage in ten elementary schools in Karawang, a city in West Java, Indonesia. The result of trial usage reveals the process of learning dance \& drama. The character of the students develops very well and consistently. 


\section{Conclusion}

This paper aims to explore the way to inculcate moral values among the children through dance and drama based learning. The results indicate that there are three core basis of delivering learning basis of arts where both refer to sharing the art with a significant professional experience to connect with each other in realizing to feel emotional similarities, potential in shaping moral values. Those are the process of receiving knowledge in the sense of sharpening performance with managing the learning habit. Learning model of dance and drama in elementary school that can form the character of leaners should be based on the concept of art education and the concept of character education. Based on concept of art education, teachers are required to teach dance and drama not only teach theories, but must involve students in the training of managing and producing the works of the show. While based on the concept of character education, in the process of learning the art of dance and drama leaners should be given the practice of sharpening the taste through habit learning. In the process of learning the art of dance and drama that can form the character of students in elementary school, it is necessary to pay attention to the following: (1) all students should be given the opportunity to be cast in the show; (2) with teacher guidance, each group is required to create a dance and drama story itself that will be performed; (3) in the process of performance training, teachers should always observe and record changes in students' attitude, to always conduct discussions at each end of the performance training and after the performance; and (5) at the end of the learning/ finished performances, teachers with students must make conclusions about the meaning of dance and drama lessons. This study is expected to contribute to the conceptual basis on how to inculcate the moral values among the children. Thus, moral education should be optimized within this co-curricular program.

\section{References}

[1] Gunawan H. Pendidikan Karakter. Bandung: Alfabeta. 2012.

[2] Nuh M. Desain Induk Pendidikan Karakter Kementrian Pendidikan Nasional. Jakarta: http://pendikar dikti go id/gdp/wpcontent/uploads/Desain-Induk-Pendidikan-Karakter-Kemdiknas pdf diakses pada tanggal. 2011;23.

[3] Afriyanti D, Ruqoyah S. Berbagai jenis kejahatan seperti pencurian, tawuran, dan pelecehan seks dilakukan siswa [A variety of violence such as brawl, theft and sexual harassment involving some students] 2015. Available from: http://metro.news.viva.co.id/news/read/312779-2 008-kasus-kriminal-dilakukan-anak-anak.

[4] Nuh M. Desain Induk Pendidikan Karakter. Jakarta: Kementrian Pendidikan Nasional RI; 2010.

[5] Kristjánsson K. Phronesis and moral education: Treading beyond the truisms. School Field. 2014;12(2):151-71.

[6] Huda M, Kartanegara M. Islamic Spiritual Character Values of alZarnūjī's Ta'līm al-Muta'allim. Mediterranean Journal of Social Sciences. 2015;6(4):229

[7] Huda M, Kartanegara M. Curriculum conception in the perspective of the book ta'lim al-muta'allim. International Journal of Education and Research. 2015;3(2):221-32.

[8] Nucci L, Krettenauer T, Narváez D. Handbook of moral and character education: Routledge; 2014

[9] Lickona T. Educating for character: How our schools can teach respect and responsibility: Bantam; 2009

[10] Huda M, Sabani N, Shahrill M, Jasmi KA, Basiron B, Mustari MI. Empowering Learning Culture as Student Identity Construction in Higher Education. Student Culture and Identity in Higher Education: IGI Global; 2017. p. 160-79.

[11] Noddings N. Caring: A relational approach to ethics and moral education: Univ of California Press; 2013.

[12] Lovat T, Toomey R. Values education and quality teaching: The double helix effect: Springer Science \& Business Media; 2009

[13] Noddings N, Brooks L. Teaching Controversial Issues: The Case for Critical Thinking and Moral Commitment in the Classroom: Teachers College Press; 2016.

[14] Schwartz KD, Fouts GT. Music preferences, personality style, and developmental issues of adolescents. Journal of youth and adolescence. 2003;32(3):205-13.
[15] Volk TM. Music, education, and multiculturalism: Foundations and principles: Oxford University Press on Demand; 2004.

[16] Barrett FS, Grimm KJ, Robins RW, Wildschut T, Sedikides C, Janata P. Music-evoked nostalgia: affect, memory, and personality. Emotion. 2010;10(3):390

[17] Phenix PH. Realms of meaning. 1964

[18] Kallinen K, Ravaja N. Emotion-related effects of speech rate and rising vs. falling background music melody during audio news: The moderating influence of personality. Personality and individual differences. 2004;37(2):275-88

[19] Corrigall KA, Schellenberg EG, Misura NM. Music training, cognition, and personality. Frontiers in psychology. 2013;4

[20] Delsing MJ, Ter Bogt TF, Engels RC, Meeus WH. Adolescents' music preferences and personality characteristics. European Journal of Personality. 2008;22(2):109-30.

[21] Klein J. From children's perspectives: A model of aesthetic processing in theatre. The Journal of Aesthetic Education. 2005;39(4):40-57.

[22] Richmond G, Striley J. Making meaning in classrooms: Social processes in small-group discourse and scientific knowledge building. Journal of Research in Science Teaching. 1996;33(8):839-58.

[23] Thomas JW. A review of research on project-based learning. 2000

[24] Wee LK-N, Kek MYCA. Authentic problem-based learning: Rewriting business education: Prentice Hall; 2002.

[25] Othman R, Shahrill M, Mundia L, Tan A, Huda M. Investigating the relationship between the student's ability and learning preferences: Evidence from year 7 mathematics students. The New Educational Review. 2016;44(2):125-38.

[26] Huda M, Kartanegara M, Zakaria GAN. The Effect of Learning Strategy of Reading Aloud on Students' Achievement in the Subject of Islamic Studies at Secondary School in Semarang. International Journal of Education and Research. 2015;3(2):577-88.

[27] Huda M, Kartanegara M. Aim Formulation of Education: An Analysis of The Book Ta'lim al-Muta'allim. International Journal of Humanities and Social Science. 2015;5(3).

[28] Mack S. Where the rainbow speaks and catches the sun: An occupational therapist discovers her true colors. Occupational Therapy in Mental Health. 2002;17(3-4):43-58

[29] Huda M, Yusuf JB, Azmi Jasmi K, Zakaria GN. Understanding Comprehensive Learning Requirements in the Light of al-Zarnūjī's Ta 'lim al-Muta 'allim. SAGE Open. 2016;6(4):2158244016670197.

[30] George D, Stickle K, Rachid F, Wopnford A. The association between types of music enjoyed and cognitive, behavioral, and personality factors of those who listen. Psychomusicology: A Journal of Research in Music Cognition. 2007;19(2):32.

[31] Huda M, Jasmi KA, Alas Y, Qodriah SL, Dacholfany MI, Jamsari EA Empowering Civic Responsibility: Insights From Service Learning. Engaged Scholarship and Civic Responsibility in Higher Education. 2017:144-65.

[32] Huda M, Kartanegara M. The Significance of Educative Environment to the Character Development. International Journal for Innovation Education and Research. 2015;3(3).

[33] Huda M, Jasmi KA, Mustari I, Basiron B, Sabani N. Traditional Wisdom on Sustainable Learning: An Insightful View From AlZarnuji's Ta 'lim al-Muta 'allim. SAGE Open. 2017;7(1):2158244017697160.

[34] Anshari M, Almunawar MN, Shahrill M, Wicaksono DK, Huda M. Smartphones usage in the classrooms: Learning aid or interference? Education and Information Technologies. 2017:1-17.

[35] Huda M, Maseleno A, Shahrill M, Jasmi KA, Mustari I, Basiron B. Exploring Adaptive Teaching Competencies in Big Data Era. International Journal of Emerging Technologies in Learning. 2017;12(3).

[36] HUDA M, JASMI KA, HEHSAN A, MUSTARI MI, SHAHRILL M, BASIRON B, et al. Empowering Children with Adaptive Technology Skills: Careful Engagement in the Digital Information Age. International Electronic Journal of Elementary Education. 2017;9(3).

[37] Huda M, Yusuf JB, Azmi Jasmi K, Nasir Zakaria G. al-Zarnūjī’s concept of knowledge ('ilm). SAGE Open. 2016;6(3):2158244016666885

[38] Huda M, Jasmi K, Mohamed A, Wan Embong W, Safar J. Philosophical Investigation of al-Zarnūjī's Ta'līm al-Muta'allim: Strengthening Ethical Engagement into Teaching and Learning. The social science. 2016;11(22):5516-9. 